


\section{NOTES TO CONTRIBUTORS}

1. Manuscripts should be typewritten on one side only on A4 paper, with double spacing and wide margins. Three copies should be submitted, and the approximate number of words stated.

2. References should be referred to in the text by giving, in brackets, the surname of the author and should be listed in numerical order at the end of the article, as follows:

BOOKS: Author's name and initials; year of publication (in brackets); title of book underline; publisher, page reference, if appropriate.

ARTICLES: Author's name and initials; date of publication (in brackets); title of article; abbreviated title of journal underlined; volume and number.

3. Footnotes should be kept to a minimum.

4. Each article should be prefaced with a brief resume.

5. Contributors are invited to submit a brief biographical note and a current photograph suitable for printing.

6. All manuscripts submitted will be reviewed by three referees. Manuscripts may be accepted for publication, returned for revision or rejected. The Editor's decision is final.

7. All manuscripts and editorial communications should be addressed to:

The Editor,

Australian Child and Family Welfare,

C/- Department of Social Work,

La Trobe University,

Plenty Road,

Bundoora, Vic.

All Book Reviews should be addressed to: The Book Review Editor, at the above address.

8. All rights of reproduction are strictly reserved.

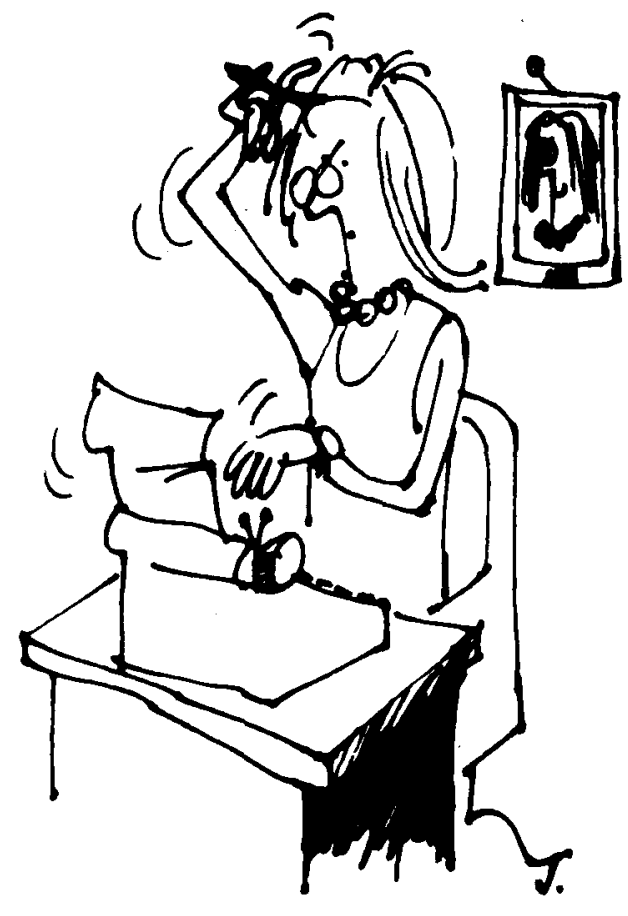

\section{Australian Child and Family Welfare Subscriptions}

Subscriptions to Australian Child \& Family Welfare are based on a calendar year. All new subscribers will receive all previous issues for 1985 .

\section{Annual Rates}

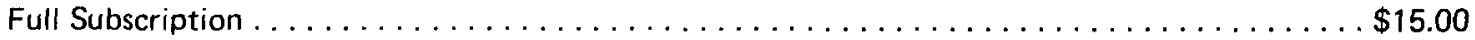

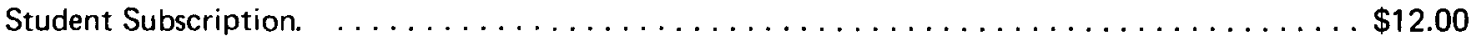

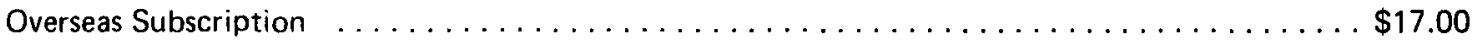

Send subscription form with cheque or money order (payable to "Australian Child \& Family Welfare") to:

The Children's Bureau of Australia, P.O. Box 13, Black Rock, Vic. 3193

NAME (IN BLOCK LETTERS)

MAILING ADDRESS

IF STUDENT, NAME OF SCHOOL, COLLEGE OR UNIVERSITY AND FACULTY

Please find enclosed Cheque/Money Order for $\$ \ldots \ldots \ldots$ being

* Full/Student/Overseas (state number of subscriptions ........) subscription.

* Circle appropriate subscription. 